\title{
Does Thucydides Portray Pericles as Good or Bad for Athens' Democracy?
}

\author{
Fenglin Qiu $^{1 *}$ \\ ${ }^{1}$ Woodside Priory School \\ ${ }^{*}$ Corresponding author. Email: fqiu22@priorypanther.com
}

\begin{abstract}
This essay critically examines the role Pericles played in Athens' democracy from the view of Thucydides. Contrary to popular belief, Athens' democratic structures had a considerable number of systematic loopholes, and Thucydides believes that Pericles took hold of the flaws in the Athenian political system with his personal charm and contagious passion [1]. Freedom of speech and freedom of expression are priorities in a democracy society. Yet, Pericles's unparalleled leadership disproportionately swayed public opinions and drowned out dissenting voices in the society. His unmatched sociopolitical influence undermined the basis of democracy and blinded the general public, making this widely acclaimed hero a villain in disguise. However, there exist counterarguments to Thucydides' views. Some suggest that Athens was in desperate need of a stronghold leader to unify and strengthen Athens' army in order to fend off foreign enemies and conflicting political ideologies. Despite the existing counterargument, it is believed that the cons of Pericles' ruling outweigh the pros due to the severity of the risk to democracy it has posed.
\end{abstract}

Keywords: Athens'democracy, Pericles, Thucydides

\section{INTRODUCTION}

Democracy is a highly debated political ideology that is pivotal to the development of human civilization. Arguably, the first emergence of democracy occurred in Athens in 6th century BC. Though acclaimed by historians around the world, Athenian democracy was far from perfect, and was once threatened by the existence of a powerful ruling figure, Pericles. In Thucydides' work, Pericles was analysed and presented as a dangerous leader hiding behind his spectacular persuasion and widespread popularity.

When most parts of the world lived under rigid hierarchical scale and monarchical society with centralized power, the city of Athens practiced democracy where people supposedly had a say in their public affairs. Although women, children, and slaves were second-class citizens forbidden from participating in governmental voting or the democratic system, individuals recognized as Athenian citizens had the opportunity to vote regardless of their wealth accumulation or social status. To be classified as an Athenian citizen, one needed to be male, over the age of eighteen, had completed their military services, and had two Athenian parents, meaning that the majority of the society was in fact disenfranchised. Nonetheless, democracy works exceptionally well when the nation or society has a well-set institution, relatively educated citizens, and a capable leader. Undoubtedly, Pericles shaped democracy in Athens by influencing many to seek glory and honour with his excellency in rhetorical speeches. Thucydides introduces Pericles as a man "wielding greatest influence both in speech and in action" when first introducing the Athenian leader. Indeed, military expertise and oration skills made Pericles an outstanding figure in Greek history who led the Athenians to shower in military glory and influenced the Council. The string of re-elections can be explained by Pericles' numerous military successes, but the brutal events also impacted the Athenian democracy. Victory enveloped the leader in a godly charisma that, in turn, gave Pericles unparalleled power and trust from the general public. Though Pericles was an individual member of the Athenian community, his words could sway public opinions in going into war, as illustrated in the examples I list out in the following paragraphs. It is certain that Pericles greatly contributed to the preservation of law, revival of Athenian culture, and reconstruction of governmental branches such as the Areopagus. However, by examining Thucydides' the History of the Peloponnesian War, I have come to realize that Pericles actually harmed Athenian democracy when 
his oration power dictated the public votes and could easily influence the mass's opinions in almost all aspects of social and political affairs. Extreme power in swaying people's mind comes hand in hand with the danger of arbitrary decisions, the people's inability of selfgoverning, and even prevention of Athenian democracy.

\section{TEXT ANALYSIS}

Thucydides introduces Pericles in Book 1 section 5 as "a man of the greatest ability both with words and actions", showing how Pericles was a capable leader at a time of crisis for the Athenians. Additionally, Thucydides accurately points out Pericles' ruling style of not being "carried away by the people, but he was the one guiding the people." In other words, Pericles was not a typical democratic leader who based his political judgment and narratives on the desires of the population, but a charismatic leader who actively impacted the thoughts of his followers. It is true that Pericles' eloquent speeches and rhetorical skills were outstanding throughout Athens's history, and he was successful at convincing others to believe what he regarded as right. Pericles' speech about fighting the Peloponnesian serves as an excellent example. In the speech, Pericles openly declared that his opinion of the war was consistent with his previous belief that the Athenians should not surrender to the Peloponnesian army. To persuade the citizens, Pericles not only recalled the time when their forefathers had defeated enemies, but also listed out pragmatic methods of winning the war such as unifying citizens and strengthening the Athenian navy. As a gifted public speaker, Pericles effectively combined passionate speaking techniques with powerful logical reasoning supported by historical evidence. With such a winning combination of ethos, logos, and pathos, he was able to evoke positive emotional reactions from his audience while informing them with intelligent and thoughtful strategies to achieve their common goals. Unlike some potential Athenian rulers at the time, Pericles was an assertive decision maker instead of an agreeable yeasayer who followed the public opinion blindly [2]. Interestingly, in his speeches to the public, his oratory ability always addressed people as if they were gullible young children who trusted the authority and the adults unconditionally. To make him an even more formidable influencer, Pericles was also fully aware of his leadership ability to enlighten the crowd and to sway the Athenian citizens' mind, and he implicitly praised himself at the Funeral Oration. With victorious pride, Pericles publicly endorsed the Athenian democratic tradition of engaging in thorough and civic-minded discussions before any action is taken. He passionately stated that "Athenians [decided] public questions for [themselves] or at least [endeavoured] to arrive at a sound understanding of them in the belief that it is not debate that is a hindrance to action, but rather not to be instructed by debate before the time comes for action." As observed from excerpts of his renowned speeches, Pericles indeed mastered the art of oration which synthesized both authority and pedagogy. On top of his extraordinary rhetorical talent, the development of Athenian military strength under Pericles' leadership was not to be underestimated. Pericles equipped himself with an abundance of miliarial knowledge so that he could instruct the army with advanced battling strategies [3]. He also preached perseverance, bravery, loyalty, and other favourable qualities to the soldiers in order to increase their dedication to defending Athenian territories.

However, although many historians and sources have common commendation of Pericles and his oratory talent, they do not always praise him for it. While the power of words and personal charms rendered Pericles uncountable political success, his ability to sway the public opinion to an extreme extent undermined Athenian democracy. Even though the Athenian democracy encouraged all citizens to actively participate in discussion of public affairs, the inexperienced novices and the young and impressionable members of the community sometimes felt ashamed when making mistakes in public, or that they mindlessly adopt Pericles' narrative without any critical thinking. True democracy encourages independent thoughts, open-ended discussions, and freedom of expression of every member of society [4]. Homogenous thinking and the lack of suspicion towards authorities cultivate an unfavourable environment for the growth of democracy and instead foster a recipe for dictatorship. But as a master of oratory like Pericles, he took advantage of his exceptional persuasiveness to dominate the public discussions, limiting others to express their concerns on decisions that supposedly required collaborative debates. In all three essential Pericles speeches documented by Thucydides, Pericles alone convinced everyone at the assembly to think like him and act as he wished. To be more specific, the first speech related to the declaration war, the Funeral Oration pushed Athenians into continuous conflict with the Peloponnesian, and the third harangue stimulated the citizens to endure their circumstance under disturbances and the plague. Pericles' exceptional oratory posed an alarming threat to critical thinking and created echo chambers in which individual opinions were invalidated or disregarded. Speaking elaborately and powerfully, Pericles could easily turn black into white. Some critics saw Pericles "thundering" and "lightening" when he harangued the audiences, gradually influencing them to rely on his decision-making process that was almost impossible to alter. Yet, any reflection on the truth of democracy indicates that real democratic society tends to secure every citizen's right to express his or her opinions, focuses on institution establishment, and ensures the people's ability to govern themselves. Pericles, nevertheless, guided his people to become intellectually dependent on him and to be vulnerable when without a leader with outstanding political savvy and phenomenal 
management. To a degree, the solemnity and power of Pericles' words negatived impacted his reputation among Athenian intellectuals, and he was regarded by the general academia as anti-democracy or overly dominant.

Indeed, the essence of Athenian democracy is to hear from all citizens and accept diverse opinions instead of permitting a leader to dominate the public mind. As Thucydides concluded in his final panegyrics that "Athens, though in a name of democracy, gradually became in fact a government ruled by its foremost citizens" (Book 2 Paragraph 65 sentence 9), the pathetic reality was that Pericles' socio-political influence brainwashed the population and inevitably eclipsed the integrity of Athenian democracy. Thucydides also declared that rulers that have strong military and oration powers are "the first of the Athenians" (Book 1 Paragraph 139). Pericles' monarchy, defined by the historian of the Peloponnesian War historian, was a representation of the unscrupulous tyrant. While Pericles' admirers believed that him was their beneficent sovereign, other scholars such as Thucydides pointed out that he was a dangerous dictator who abused his power and authority. Either way, the Athenian public appeared to be a mindless puppet manipulated by their ruler's oratory skills and his overwhelming popularity. These rulers like Pericles could dominate the whole Athenian politics field without challenge. In particular, Pericles seemed so outrageously dominating that he was not regarded like other civic individuals. Pericles alone confronted the needs and disagreement of all Athenians who form a homogeneous block before him, and he purely uses the oration techniques to make the public recognize his superiority when it comes to military and civil decision makings. According to Thucydides, Pericles "restrained the multitude while respecting their liberties, and led them rather than was led by them", indicating that he held absolute power with his words and actions. Winning excessive support from blind followers wooed by his splendid speeches, Pericles inevitable deprived the people's right of making decisions for themselves. A subordinate point about Pericles's influence on Athenian democracy is that he did not give other city-states in the Delian League decent respect for them to submit to Athenian rule. It is undemocratic for Pericles to look down at its allies while he claimed to be democratic and wanted other city-states to follow Athenian governmental forms. The unequal mindset reflected by the way Pericles treated neighboring ally states served as a solid parallel to the political and social disparity he created in the city of Athens itself.

\section{REBRUTTAL}

Given my refutation to the use of Pericles's military capability and oration strategies; and offered further explanation to why Pericles harmed Athenian democracy, some readers of this paper can still object the idea that
Pericles was an arbitrary, anti-democratic leader. They might hold onto the notion that the Athenian people were in desperate need of a unifying leader at a time of chaos within ally city-states and between Athenians and the Spartans. Throughout human history, in face of impending threats from formidable enemies or natural disasters, citizens of a nation are more likely unit under one assertive ruler. It is human nature to feel comforted and assured by the presence of a capable leader who truly believes in their cause. That being said, the sophisticated geopolitics in the region definitely complicated the situation and offered legitimate reasons for Athenian people to support a forceful and self-assured leading figure like Pericles at times of crises. In other words, the supporters of Pericles' leadership believe that the people needed a strong-willed central commander to guide them in a time of national emergency. During Pericles's ruling era, the Athenian forces succeeded in controlling the waters around Peloponnesian peninsula, reaching the climax of its military success.

Although there are valid arguments supporting Pericles' authoritative style of governance, I advocate for a more nuanced perspective that takes the bigger picture into account. As critical thinkers, we have to look at historical facts to determine whether Pericles dictating Athens was beneficial in the long term. In The Peloponnesian War, Thucydides sees the death of Pericles as a turning point in the history of Athens. He points out Pericles's reign like a dividing line between a community led by an elite and a self-governing city to the hands of demagogues. Thucydides' arguments suggest that Pericles created an elitist society that excluded the democratic participation of many members of the community [5]. Afterall, equitable engagement in social and public affairs by all citizens was what Athens was known for and was set it apart from neighboring states. If Pericles' centralized power took away the essence of Athens, then in the grand scheme of things, it was detrimental to the development of Athens' significant cultural values.

In the funeral appreciation of the dead leader, Thucydides contrasts Pericles and his potential successors, saying "for so long he presided over the affairs of the state in time of peace he pursued a moderate policy and kept the city in safety, and it was under him that Athens reached the height of her greatness...But the successors of Pericles, being more on an equality with one another and yet striving each to be first, were ready to surrender to the people even the conductor public affairs to suit their whims". Because of these potential leaders were not as capable as Pericles, they had to seek other ways to win the trust and respect from the people [2]. They competed against each other by pleasing the public, giving the public what they want, and not considering the consequences of doing so. For so long the leader had dominated the political affairs in Athens and the public had been puppets of those who led them that 
they became incapable of ruling themselves. The Peloponnesian War proved the idea of people do not continue to trust their leaders if they are almost of the same level in ability of ruling [6].

\section{CONCLUSION}

To sum up, Pericles's long-term ruling period gradually deprived the people's right to participate in politics in an authentic Athenian democracy and led the following leaders to be incapable. His irresistible personal charm as a community leader and his incredible persuasion skills were first considered a gift by the average Athenian at the time, yet an overview of social and political changes during his reign revealed to historians and scholars that his disproportional power undermined the foundation of Athenian democracy. His natural leadership talents became a deep-rooted poison that endangered the most crucial element of Athenian democracy, and this paradoxical outcome serves as a warning to the world that unchecked and centralized political influence can smother innovation, creativity, and freedom of speech, and other necessary components of democracy.

\section{REFERENCES}

[1] Thucydides, M. I. Finley, Rex Warner, History of the Peloponnesian War, Penguin Classics, 1972

[2] Kagan, Donald. Pericles of Athens and the Birth of Democracy. Simon and Schuster, 1998.

[3] Smart, Anthony. "Pericles of Athens: Democracy and Empire." Historians on Leadership and Strategy. Springer, Cham, 2020. 255-267.

[4] Maskivker, Julia. "Participation and rights in Athenian democracy: A habermasian approach." The European Legacy 15.7 (2010): 855870.

[5] Loren, J., and I. I. Samons. "Mass, Elite, and HopliteFarmer in Greek History." (1998): 99-123.

[6] Hanson, Victor Davis. A war like no other: How the Athenians and Spartans fought the Peloponnesian War. Random House Incorporated, 2005. 